\title{
Socioscientific-Issues Based Classroom Intervention on Grade 10 Students' Learning Achievement and Scientific Reasoning
}

\author{
Linda Khajornkhae \\ Faculty of Education, Mahasarakham University, Thailand \\ Prasart Nuangchalerm (Corresponding author) \\ Faculty of Education, Mahasarakham University, Thailand \\ E-mail: prasart.n@msu.ac.th
}

Received: November 3, 2021 Accepted: December 8, 2021

Published: December 31, 2021

doi:10.5296/jei.v7i2.19204 URL: https://doi.org/10.5296/jei.v7i2.19204

\begin{abstract}
Socioscientific-issues based instruction can promote science to students as a tool for necessary learning in the disruptive world. This instruction helps students critique and response as its nature of science, gaining higher-ordered thinking, and discussing with scientific reasoning. The objectives of this study were to compare learning achievement and scientific reasoning of grade 10 students. The topic "DNA technology" was employed with 90 grade 10 students from 2 classrooms. The quasi-experimental research was designed by comparing learning achievement and scientific reasoning between 2 learning organizations. The research tools were socioscientific-issues based and inquiry-based lesson plans, the achievement test consist of 30 items of 4 choices multiple test and scientific reasoning test. The statistic used to test the hypothesis was independent t-test. The results indicated that students had no difference score of learning achievement between learning organizations. While socioscientific-issues based learning had score of scientific reasoning higher than inquiry-based learning at the .05 level of statistically significance. The study can summarize that socioscientific-issues based learning can promote scientific reasoning to science classroom.
\end{abstract}

Keywords: Inquiry, Learning achievement, Scientific reasoning, Socioscientific-issues 


\section{Introduction}

Science is the learning process and knowledge about natural world phenomena, which all human beings should learn for working and living in our societies. Today's world assumes that science plays an important role in economic, social, environmental, and educational development (Bulmer, 2021). Science is now can be called a society of the modern world which everyone needs to develop potential of science learning. Scientific knowledge is not only used to improve quality of life, but also helps to learn and live with uncertainty world (Prachagool \& Nuangchalerm, 2021; Turhan \& Demirci, 2021). Science enhances the human capacity to develop in connecting multi-dimensions studies. It also helps humans to have an accurate understanding of exploitation, so everyone needs to be developed to know science in order to have understandings of nature and the technology created by humans (El Halwany et al., 2021).

There are many forms of educational management to develop science that will encourage students to develop learning processes, especially learning management that focuses on learners. To develop students' scientific process skills, knowledge quests, and problem-solving skills, which are goals related to the learning management of the science learning areas (Duangrawa \& Nuangchalerm, 2020; Juhji \& Nuangchalerm, 2020). It focuses on enabling students to develop science process skills, thinking method, rational thinking, creative thinking, analytical thinking, critical thinking. These are important skills in researching knowledge that helps students the ability to solve problems in systematically. Decisions can be made using a wide range of information and verifiable testimonies (Emery et al., 2017).

Science is the common culture of the modern world, everyone must be developed knowledge and understandings into a science literacy. Scientific processes, including good attitudes towards science and technology, can use scientific knowledge in the daily life in a quality way. It can participate in scientific issues that arise in society and can be justified on the basis of science (Lawson, 2004). The management of science learning is intended to develop a complete humanity, logic, and is known to use the process of knowledge-seeking (Kinslow \& Sadler, 2018; Ke et al., 2020; Zangori et al., 2020).

Learning management about science, society relevant to its movement as in current issues. It can improve students' learning achievement, critical thinking, nature of science, and scientific reasoning. The socioscientific-issues based instruction is subsequently driven to develop the potential of students to make decisions under scientific reasoning (Sadler, 2011; Zeidler et al., 2011; Kinskey \& Zeidler, 2021). There is an ethical scientific dimension, bioethics, reasoning, and emotional development (Pharanat \& Nuangchalerm, 2015; Ritsreeboon \& Nuangchalerm, 2016; Svenaeus, 2017). Socioscientific-issues is a learning arrangement using the social issues that arise today and is yet to be inconclusive (Reis, 2014).

This is being debated in society due to differences in opinions about the accuracy, suitability of the concept. Scientific processes and technologies are practical problems, the problem is of interest to students. There are several solutions, endless answers for the natural phenomenon in appearances (Lin \& Mintzes, 2010). It's a complicated problem that doesn't end. The issue 
was debated under multiple views and lacked a clear answer to negotiations. The issues to be taken it into account must be based on morality and ethics, including science and non-science stories relevant to society movement (Evren-Yapicioglu, 2018; Foulk et al., 2020; Garrecht et al., 2020).

Society, economy and environment create an integration thought, social arguments within society. Thinking and doing with nature of science, it is as a tool to help students learn science, a meaningful learning that corresponds to the real life of learners (Hancock et al., 2020). The effective instruction in the modern classroom, students are socially responsible, are able to apply real-life scientific knowledge (Jafari \& Meisert, 2019; Ke et al., 2020). The ability to reason scientifically is the ability to seek evidence or testimony, including ideas which students should be improved.

Students have ability to giving a reason scientifically that will be able to explain the phenomenon and make scientific decisions using scientific evidence or testimony. They obtained data by collecting information properly or through disputed discussions. Exchange of views leads to reasonable conclusions (Halim \& Saat, 2017). Scientific principles or theories can be established by linking theory into practices. Those principles or theories, with their initial assumptions, and those who have the ability to reason scientifically (Ottander \& Simon, 2021). This study has two hypotheses as follows:

(1) Students who study using socioscientific-issues based learning have higher learning achievement than inquiry-based learning.

(2) Students who study using socioscientific-issues based learning have higher scientific reasoning than inquiry-based learning.

\section{Materials and Methods}

\subsection{Participants}

Students who are attending grade 10 in the semester 2, academic year 2020. They are studying at Kalasin Pittayasan School, Secondary School Service Area 24, Thailand from 582 students, 14 classrooms. The samples are 90 of grade 10 students, obtained by cluster random sampling. Two classrooms divided into 45 students of socioscientific-issues based learning and 45 students of inquiry-based learning.

\subsection{Variables}

Independent variables are learning organization, including socioscientific-issues based learning and inquiry-based learning.

Dependent variables consisted of learning achievement and scientific reasoning.

\subsection{Research Tools}

Research tools include 8 learning plans of socioscientific-based learning and of inquiry-based learning topic "DNA technology", each learning plans consisted of 12 hours; a multiple choice with 30 achievement tests.; and scientific reasoning test with 8 situations. 


\subsection{Data Collection}

The study employed pre-experimental research with two groups posttest design for data collection.

\subsection{Data Analysis}

The data were collected and analyzed based on testing 2 research questions:

(1) Students who study using socioscientific-issues based learning have higher learning achievement than inquiry-based learning? The data was test by independent t-test for comparing learning achievement between two groups.

(2) Students who study using socioscientific-issues based learning have higher scientific reasoning than inquiry-based learning? The data was test by independent t-test for comparing scientific reasoning between two groups.

\section{Results}

Mean scores of learning achievement between two groups were not shown statistical differences. But the mean scores of scientific reasoning between two groups were shown statistical differences at .05 level (Table 1).

Table 1. Comparing learning achievement and scientific reason between two groups

\begin{tabular}{|l|l|l|l|l|l|l|l|l|}
\hline \multicolumn{2}{|l|}{} & \multicolumn{2}{|l|}{ Socioscientific-issues based learning } & \multicolumn{2}{|l|}{ Inquiry-based learning } & \multirow{2}{*}{$\mathrm{t}$} & \multirow{2}{*}{$\mathrm{p}$} \\
\cline { 1 - 6 } Variable & $\mathrm{n}$ & $\bar{X}$ & S.D. & $\bar{X}$ & S.D. & & \\
\hline Learning achievement & 45 & 19.60 & 3.86 & 19.44 & 2.56 & 0.225 & .822 \\
\hline Scientific reasoning & 45 & 39.80 & 2.15 & 34.44 & 2.44 & 11.059 & .000 \\
\hline
\end{tabular}

Table 1, the mean sore of leaning achievement, socioscientific-issues based learning was 19.60, while inquiry-based learning showed mean score was 19.44. The independent t-test was not shown statistical differences between group. Scientific reasoning of students learning with socioscientific-issues based learning showed mean score was 39.80, the inquiry-based learning had mean score was 34.44. The statistical testing was shown statistical differences at .05 level.

\section{Discussion}

The study found that there were issues that should be discussed. The mean sore of leaning achievement, socioscientific-issues based learning and inquiry-based learning were not shown statistical differences between group. Scientific reasoning of students who learned by socioscientific-issues based learning and inquiry-based learning had significant differences at .05 level of statistics. The finding was not made surprisingly reported due to each lesson plans meet the learning standards and indicators which appeared in national curriculum. 
However, scientific reasoning was the highlight of experimentation. Socioscientific-issues based learning can encourage students to express and discuss science by suitable reasoning. The use of open-ended questions stimulates analytical thought processes, as well as activities that allow all students to participate in finding answers and sharing ideas (Panasan \& Nuangchalerm, 2010; Wongsri \& Nuangchalerm, 2010; Siribunnam et al., 2014; Cahyarini et al., 2016; Siribunnam et al., 2019; Nida et al., 2021).

Socioscientific-issues based learning allowed students increase in scientific reasoning. Students might want to go their success of learning that requires understanding of the content of the lesson in order to have an understanding. It can improve student scientific reasoning, make decision based on evidences, explain of what they learn through scientifically discussed (Pitpiorntapin \& Topcu, 2016; Nurtamara, 2019). In search of important issues, it is a step which teachers take the issues that are being disputed in society as issues related to science. It can be searched from social medium, search engine, or academic publications. Then apply issues to analyze the conformity of standards, organize learning activities and making the most appropriate choices with consideration as well. It is a widely discussed issue in society, appearing in various media articles appeared in journals or newspapers, TV shows or on social media, etc. (Shin et al., 2017; Bayram-Jacobs et al., 2019; Genisa \& Subali, 2020).

\section{Conclusion}

Students had no difference score of learning achievement between learning organizations. While socioscientific-issues based learning had score of scientific reasoning higher than inquiry-based learning with statistically significance at the .05 level. It can be summarized that socioscientific-issues based learning can promote scientific reasoning to students as well.

\section{Acknowledgements}

This research is supported by Mahasarakham University, Thailand.

\section{References}

Bayram-Jacobs, D., Henze, I., Evagorou, M., Shwartz, Y., Aschim, E. L., Alcaraz-Dominguez, S., ... Dagan, E. (2019). Science teachers' pedagogical content knowledge development during enactment of socioscientific curriculum materials. Journal of Research in Science Teaching, 56(9), 1207-1233. https://doi.org/10.1002/tea.21550

Bulmer, M. I. (2021). Social science and social policy. Routledge, London.

Cahyarini, A., Rahayu, S., \& Yahmin, Y. (2016). The effect of 5e learning cycle instructional model using socioscientific issues (SSI) learning context on students' critical thinking. Jurnal Pendidikan IPA Indonesia, 5(2), 222-229. https://doi.org/10.15294/jpii.v5i2.7683

Duangrawa, A., \& Nuangchalerm, P. (2020). Torrance's future problem-solving instruction: Developing students' problem-solving ability. Jurnal Ilmiah Pendidikan Fisika Al-Biruni, 9(2), 251-257. https://doi.org/10.24042/Jipfalbiruni.v9i2.6308

El Halwany, S., Bencze, L., Hassan, N., Schaffer, K., Milanovic, M., \& Zouda, M. (2021). Becoming alive within science education (research): Thinking with life history (ies), bodies 
and stickiness. Cultural Studies of Science Education, 16(1), 85-107. https://doi.org/10.1007/ s11422-020-09994-4

Emery, K., Harlow, D., Whitmer, A., \& Gaines, S. (2017). Compelling evidence: An influence on middle school students' accounts that may impact decision-making about socioscientific issues. Environmental Education Research, 23(8), 1115-1129. https://doi.org/ 10.1080/13504622.2016.1225673

Evren-Yapicioglu, A. (2018). Advantages and disadvantages of socioscientific issue-based instruction in science classrooms. International Online Journal of Education and Teaching, 5(2), 361-374.

Foulk, J. A., Friedrichsen, P. J., \& Sadler, T. D. (2020). Science in socio-scientific issues. The Science Teacher, 87(7), 35-39.

Garrecht, C., Eckhardt, M., Höffler, T. N., \& Harms, U. (2020). Fostering students' socioscientific decision-making: exploring the effectiveness of an environmental science competition. Disciplinary and Interdisciplinary Science Education Research, 2(1), 1-16. https://doi.org/10.1186/s43031-020-00022-7

Genisa, M. U., \& Subali, B. (2020). Socio-scientific issues implementation as science learning material. International Journal of Evaluation and Research in Education, 9(2), 311-317. https://doi.org/10.11591/ijere.v9i2.20530

Halim, M., \& Saat, R. M. (2017). Exploring students' understanding in making a decision on a socioscientific issue using a persuasive graphic organiser. Journal of Baltic Science Education, 16(5), 813-824. https://doi.org/10.33225/jbse/17.16.813

Hancock, T. S., Friedrichsen, P. J., Kinslow, A. T., \& Sadler, T. D. (2019). Selecting socio-scientific issues for teaching. Science \& Education, 28(6), 639-667. https://doi.org/ 10.1007/s11191-019-00065-X

Jafari, M., \& Meisert, A. (2019). Activating students' argumentative resources on socioscientific issues by indirectly instructed reasoning and negotiation processes. Research in Science Education, 51(Suppl. 2), 5913-5934. https://doi.org/10.1007/s11165-019-09869-x

Juhji, J., \& Nuangchalerm, P. (2020). Interaction between scientific attitudes and science process skills toward technological pedagogical content knowledge. Journal for the Education of Gifted Young Scientists, 8(1), 1-16. http://dx.doi.org/10.17478/ jegys.2020.XX

Ke, L., Sadler, T. D., Zangori, L., \& Friedrichsen, P. J. (2020). Students' perceptions of socio-scientific issue-based learning and their appropriation of epistemic tools for systems thinking. International Journal of Science Education, 42(8), 1339-1361. https://doi.org/ 10.1080/09500693.2020.1759843

Kinskey, M., \& Zeidler, D. (2021). Elementary preservice teachers' challenges in designing and implementing socioscientific issues-based lessons. Journal of Science Teacher Education, 32(3), 350-372. https://doi.org/10.1080/1046560X.2020.1826079 
Kinslow, A. T., \& Sadler, T. D. (2018). Making science relevant. The Science Teacher, 86(1), 40-45. https://doi.org/10.2505/4/tst18_086_01_40

Lawson, A. E. (2004). The nature and development of scientific reasoning: A synthetic view. International Journal of Science and Mathematics Education, 2(3), 307-338. https://doi.org/ 10.1007/s10763-004-3224-2

Lin, S. S., \& Mintzes, J. J. (2010). Learning argumentation skills through instruction in socioscientific issues: The effect of ability level. International Journal of Science and Mathematics Education, 8(6), 993-1017. https://doi.org/10.1007/s10763-010-9215-6

Nida, S., Mustikasari, V. R., \& Eilks, I. (2021). Indonesian pre-service science teachers' views on socio-scientific issues based science learning. EURASIA Journal of Mathematics, Science and Technology Education, 17(1). 1-11. https://doi.org/10.29333/ejmste/9573

Nurtamara, L. (2019). The importance socio-scientific issues of in biology learning preparing students as a 21st century society. Journal of Physics: Conference Series, 1157(2), 022070. https://doi.org/10.1088/1742-6596/1157/2/022070

Ottander, K., \& Simon, S. (2021). Learning democratic participation? Meaning-making in discussion of socioscientific issues in science education. International Journal of Science Education, 43(12), 1895-1925. https://doi.org/10.1080/09500693.2021.1946200

Panasan, M., \& Nuangchalerm, P. (2010). Learning outcomes of project-based and inquiry-based learning activities. Journal of Social Sciences, 6(2), 252-255. https://doi.org/ 10.3844/jssp.2010.252.255

Pharanat, W., Nuangchalerm, P., \& Sonsupap, K. (2015). Promoting reasoned argumentation in science for lower secondary students. Educational Research and Reviews, 10(3), 357-362. https://doi.org/10.5897/ERR2014.2062

Pitpiorntapin, S., \& Topcu, M. S. (2016). Teaching based on socioscientific issues in science classrooms: A review study. KKU International Journal of Humanities and Social Sciences, 6(1), 119-136.

Prachagool, V., \& Nuangchalerm, P. (2021). Perspectives of Thai educators toward $21^{\text {st }}$ century instruction. Journal of Education and Learning, 15(3), 432-437. https://doi.org/ 10.11591/edulearn.v15i3.20281

Reis, P. (2014). Promoting students' collective socio-scientific activism: Teachers' perspectives. Activist science and technology education (pp. 547-574). Springer, Dordrecht. https://doi.org/10.1007/978-94-007-4360-1_31

Ritsreeboon, J., \& Nuangchalerm, P. (2016). Promoting bioethical decision making for grade 10 students through socio-scientific issues based instruction (pp. 55-65). The Asian Conference on Education \& International Development 2016.

Sadler, T. D. (2011). Situating socio-scientific issues in classrooms as a means of achieving goals of science education. Socio-scientific Issues in the Classroom (pp. 1-9). Springer, 


\section{Macrothink}

Dordrecht. https://doi.org/10.1007/978-94-007-1159-4_1

Shin, S., Brush, T. A., \& Glazewski, K. D. (2017). Designing and implementing web-based scaffolding tools for technology-enhanced socioscientific inquiry. Journal of Educational Technology \& Society, 20(1), 1-12.

Siribunnam, S., Bednarova, R., \& Nuangchalerm, P. (2019). The effect of SSI overlap STEM education on secondary students' socio-scientific decision making. Journal of Physics: Conference Series, 1340(1), 012006. https://doi.org/10.1088/1742-6596/1340/1/012006

Siribunnam, S., Nuangchalerm, P., \& Jansawang, N. (2014). Socio-scientific decision making in the science classroom. International Journal for Cross-Disciplinary Subjects in Education, 5(4), 1777-1782.

Svenaeus, F. (2017). Phenomenological bioethics: Medical technologies, human suffering, and the meaning of being alive. Routledge, London. https://doi.org/10.4324/9781315210131

Turhan, G. M., \& Demirci, I. A. (2021). What are the 21 st-century skills for pre-service science and mathematics teachers: Discussion in the context of defined 21 st-century skills, self-skills and education curricula. Journal of Educational Issues, 7(1), 92-112. https://doi.org/10.5296/jei.v7i1.18278

Wongsri, P., \& Nuangchalerm, P. (2010). Learning outcomes between socioscientific issues-based learning and conventional learning activities. Journal of Social Sciences, 6(2), 240-243. https://doi.org/10.3844/jssp.2010.240.243

Zangori, L., Ke, L., Sadler, T. D., \& Peel, A. (2020). Exploring primary students causal reasoning about ecosystems. International Journal of Science Education, 42(11), 1799-1817. https://doi.org/10.1080/09500693.2020.1783718

Zeidler, D. L., Applebaum, S. M., \& Sadler, T. D. (2011). Enacting a socioscientific issues classroom: Transformative transformations. Socio-scientific Issues in the Classroom (pp. 277-305). Springer, Dordrecht. https://doi.org/10.1007/978-94-007-1159-4_16

\section{Copyright Disclaimer}

Copyright for this article is retained by the author(s), with first publication rights granted to the journal.

This is an open-access article distributed under the terms and conditions of the Creative Commons Attribution license (http://creativecommons.org/licenses/by/3.0/). 